\title{
NASIONALISME BANGSA DAN MELUNTURNYA SEMANGAT BELA NEGARA
}

\author{
Amalia Irfani
}

\begin{abstract}
Abstrak
"Bangsa yang besar adalah bangsa yang menghormati jasa pahlawannya", demikian pesan yang pernah disampaikan oleh Presiden pertama RI sekaligus Proklamator kemerdekaan pada saat memperingati hari Pahlawan 10 November tahun 1961. Katakata yang sederhana namun mengandung makna sangat dalam. Sukarno sepertinya telah jauh berpikir ke depan tentang berbagai hal yang akan dilalui negeri ini nanti. Jika semangat nasionalisme mengusir penjajah berkobar dizamannya, sebaliknya semangat tersebut perlahan meredup seiring kedewasaan kemerdekaan Indonesia. Kini Ibu Pertiwi berduka, dalam sebuah lantunan nada, Ismail Marzuki komposer Indonesia di era 1950an dan 1960-an, pun telah membahasakannya dalam beberapa bait lirik yang menyentuh hati.Tulisan ini secara singkat mengulas semangat nasionalisme di Indonesia, sejarah dan prosesnya. Sebuah keprihatinan terhadap keadaan negeri yang telah kehilangan semangat membangun, yang katanya kaya, santun dan bermartabat.
\end{abstract}

Kata Kunci : nasionalisme, bangsa, wawasan kebangsaan

\section{A. Pendahuluan}

"Dahulu kala, Indonesia adalah bagian dari negara-negara yang sangat dihormati, bahkan mungkin ditakuti oleh negara lain. Indonesia memperoleh kemerdekaan melalui perjuangan panjang, dengan senjata seadanya. Kemerdekaan Indonesia diraih dengan semangat persatuan, semangat yang tercermin pada sila ke 3 dasar negara
Indonesia; semangat yang dulu pernah menyala terang benderang, sekarang telah perlahan meredup. Redup disebabkan oleh ulah segelintir orang dari bangsa sendiri, yang rela menjual harga diri bangsa hanya untuk kepentingan pribadi, golongan dan politik".

Idealnya, semakin majunya sebuah negara harusnya diikuti juga 
oleh semakin tumbuh dan berkembangnya semangat nasionalisme. Dalam perjalanannya Indonesia membuktikan bahwa pemudalah generasi yang mampu merubah (agent of change) keadaan yang awalnya tidak dan kurang kondusif menjadi lebih baik. Pemuda dengan kekuatan, kecerdasannya lebih mampu berpikir secara terbuka dan toleran untuk menerima perubahan, dan pemudalah yang akan melestarikan semangat nasionalisme sampai ke anak cucunya kelak. Sebab, nasionalisme adalah roh yang menggerakkan semua elemen masyarakat dalam kehidupan berbangsa dan bernegara. Tetapi, apalah jadinya negara ini, jika semangat nasionalisme tidak lagi melekat didalam sanubari anak bangsa; apapun status sosial dan ekonominya. Di pemerintahan Jokowi ini saja misalnya, semangat jiwa nasionalisme anak bangsa telah terkoyak-koyak oleh sikap pemerintah yang tidak lagi pro rakyat. Rakyat dibuat bingung dengan aksi dan reaksi pemerintah yang terkesan lambat dan tidak lagi berpihak kepada rakyat. Walau tidak instan berproses, kenyataan tersebut akan merubah tatanan kehidupan berbangsa dan bernegara, serta menimbulkan arogansi rakyat kepada pemerintah, yang jika terus dibiarkan bukan tidak mungkin memunculkan gesekan-gesekan konflik yang berakhir dengan kekerasan.

Nasionalisme terbentuk dari interaksi antar elemen di dalam suatu bangsa dan tanggapan bangsa itu terhadap lingkungan, sejarah, dan citacitanya. Substansi nasionalisme Indonesia memiliki dua unsur; Pertama, kesadaran mengenai persatuan dan kesatuan bangsa Indonesia yang terdiri dari suku, etnik, dan agama. Kedua, kesadaran bersama bangsa Indonesia dalam menghapuskan segala bentuk pensubordinasian, penjajahan, dan penindasan dari bumi Indonesia.

$\begin{array}{crr}\text { Namun } & \text { faktanya, } & \text { seiring } \\ \text { berkembangnya } & \text { zaman, } & \text { rasa }\end{array}$
nasionalisme kian memudar. Generasi muda tidak lagi mengenal dengan baik jati diri bangsa. Generasi muda sekarang adalah generasi "galau" dengan masalah pribadi. Hal ini dibuktikan dari berbagai sikap dalam memaknai berbagai hal penting bagi Negara Indonesia. Contoh sederhana yang menggambarkan betapa kecilnya rasa nasionalisme, diantaranya masyarakat Indonesia sekarang adalah:

1. Pada saat upacara bendera, masih banyak rakyat yang tidak memaknai arti dari upacara tersebut. Upacara merupakan wadah untuk menghormati dan menghargai para pahlawan yang telah berjuang keras untuk mengambil kemerdekaan dari 
tangan para penjajah. Para pemuda seakan sibuk dengan pikirannya sendiri, tanpa mengikuti upacara dengan khidmad.

2. Pada peringatan hari-hari besar nasional, seperti Sumpah Pemuda, hanya dimaknai sebagai seremonial dan hiburan saja tanpa menumbuhkan rasa nasionalisme dan patriotisme dalam benak mereka.

3. Lebih tertariknya masyarakat terhadap produk impor dibandingkan dengan produk buatan dalam negeri, lebih banyak mencampurkan bahasa asing dengan bahasa Indonesia untuk meningkatkan gengsi, dan lain-lain.

Selain itu masih kurangnya kesadaran masyarakat untuk memasang bendera di depan rumah, kantor atau pertokoan. Bagi yang tidak mengibarkannya mereka punya berbagai macam alasan benderanya sudah sobek atau tidak punya tiang bendera, malas, cuaca buruk, dan sebagainya.

4. Sikap acuh tak acuh masyarakat khususnya para pemuda pada situasi kondisi bangsa.

Contoh diatas merupakan fenomena yang perlahan tampak ke permukaan, dan menjadi pemicu memudarnya semangat nasionalisme. Identitas bangsa seperti bendera merah putih, lagu kebangsaan Indonesia Raya dan lain sebagainya hanyalah merupakan simbol, simbol bahwa negara Indonesia masih berdiri tegak dan mampu mensejajarkan dirinya dengan bangsa lain. Hal utamanya adalah semangat berjuang dari penjajahan bangsa lain yang sekarang terbungkus oleh sistem kapital liberalisme. Slogan NKRI harga mati, setidaknya menandakan bangsa Indonesia adalah bangsa kuat dan mampu menopang dirinya sendiri. Tulisan ini akan sedikit membahas tentang semangat Nasionalisme bangsa dengan melunturnya semangat bela negara.

\section{B. Konsep Nasionalisme dan Wawasan Kebangsaan}

\section{Sejarah Nasionalisme}

Nasionalisme awalnya berkembang di daratan Eropa. Pada akhir abad ke 18 di Eropa mulai berlaku suatu paham bahwa setiap bangsa harus membentuk suatu Negara sendiri dan bahwa Negara itu harus meliputi seluruh bangsa masing-masing. Kebanyakan bangsa-bangsa itu memiliki faktor-faktor obyektif tertentu yang membuat mereka berbeda satu sama lain, misalnya persamaan keturunan, persamaan bahasa dan daerah budaya, kesatuan politik, adat istiadat dan tradisi atau juga karena persamaan agama. Gerakan 
nasionalisme dan cita-cita kebangsaan yang berkembang di eropa pada hakikatnya memiliki sifat cinta kebangsaan.

Nasionalisme yang berkembang di Eropa kemudian menjalar ke seluruh dunia. Memasuki awal abad 20 nasionalisme mulai berkembang di negara-negara Asia dan Afrika termasuk Indonesia. Nasionalisme di Asia dan Afrika bukan hanya suatu perjuangan kemerdekaan untuk melepaskan diri dari belenggu penjajahan, tetapi memiliki tujuan yang lebih mendalam, sehingga nasionalisme itu memiliki beberapa aspek seperti: (1) Aspek politik (2) Aspek Budaya. Nasionalisme bersifat menghilangkan pengaruh kebudayaan asing yang buruk dan bertujuan menghidupkan kembali kebudayaan yang mencerminkan harga diri bangsa setara dengan bangsa lain serta diakui berdaulat di semua sisi kehidupan berbangsa. Dengan kata lain semangat nasionalisme di Asia dan Afrika adalah suatu perjuangan untuk menumbangkan kolonialisme dan imprialisme; dengan ciri-ciri sebagai berikut :

1. Nasionalisme sebagai sarana untuk menumbuhkan semangat perlawanan terhadap dominasi imperialisme Barat

2. Nasionalisme menjadi peletak dasar terciptanya perubahan masyarakat Asia terutama dalam cara pandang tentang kedaerahan menjadi cara pandang seluruh bangsa.

3. Nasionalisme ditumbuhkan oleh para pemimpin intelektual yang memperoleh pengaruh positif dari pendidikan Barat seperti pendidikan modern, berpikir kritis, komitmen terhadap kemajuan ilmu pengetahuan.

4. Semangat nasionalisme tersebut terus berkembang karena para pemimpin dan pengikutnya lebih melihat masa depan dibanding masa Ialu.

Beberapa bentuk nasionalisme di dunia :

1. Nasionalisme Kewarganegaraan adalah nasionalisme yang terbentuk karena Negara memperoleh kebenaran politik dan partispasi aktif warga negaranya.

2. Nasionalisme Etnis, nasionalisme yang terbentuk karena Negara memperoleh kebenaran politik dan budaya asal atau etnis sebuah masyarakat.

3. Nasionalisme budaya adalah nasionalisme yang terbentuk karena Negara memperoleh kebenaran politik dari budaya bersama anggota masyarakat.

4. Nasionalisme romatik (Nasionalisme Identitas) adalah nasionalisme etnis yang terbentuk karena Negara 
memperoleh kebenaran politik sebagai sesuatu yang alamiah dan merupakan ekspresi suatu bangsa atau ras.

5. Nasionalisme agama; nasionalisme yang terbentuk karena Negara memperoleh legitimasi politik dari persamaan agama yang dipeluk oleh anggota masyarakat

6. Nasionalisme kenegaraan merupakan kombinasi antara nasionalisme kewarganegaraan dan nasionalisme etnis. Dalam konsep nasionalisme kenegaraan, bangsa menjadi komunitas yang memberikan kontribusi terhadap pemeliharaan dan kekuatan Negara.

Dari ciri-ciri dan bentuk-bentuk nasionalisme diatas, dapat kita lihat bahwa, nasionalisme pada hakikatnya berproses secara alami dan disesuaikan dengan keadaan masyarakat. Indonesia misalnya, unsur nasionalisme yang di tunjukkan dalam diri bangsa Indonesia sudah ada sejak lama. Hal ini dapat dilihat adanya rasa kecintaan terhadap tanah kelahiran, perlawanan rakyat bersama rajanya untuk menghadapi kelicikan dan kekejaman penjajah, khususnya Belanda. Contoh, Pada masa Kerajaan Sriwijaya dan Majapahit sudah muncul dan berkembang kecintaan terhadap tanah kelahirannya. Kedua kerajaan besar itu menyatukan wilayahwilayah kecil disekitarnya.

Perlawanan fisik terhadap
belanda adalah wujud nasionalisme bangsa untuk mempertahankan wilayahnya Pada awalnya perlawanan itu masih bersifat kedaerahan dan terpisah-pisah, karena belum ada koordinasi antara perlawanan satu dengan yang lainnya. Hal ini disebabkan karena nasionalisme perlawanan ter sebut sudah dipatahkan oleh Belanda. Disamping itu karena minimnya teknologi dan persenjataan yang dimiliki bangsa Indonesia. Penjajah memiliki studi sosial yang lebih maju, mampu memetakan kondisi masyarakat nusantara. Dengan pemetaan tersebut digunakan untuk politik pecah belah yaitu mengadu domba antar kelompok masyarakat nusantara satu dengan yang lainnya.

Dari pengalaman itu, para pemimpin merubah strategi perlawanan yaitu dengan perjuangan melalui jalur pendidikan, menumbuhkan persatuan dan kesatuan, penyadaran perlawanan yang terorganisir. Dengan kesadaran akan pentingnya pendidikan, dapat diketahui pada awal tahun 1990-an melahirkan pemuda yang cukup memadai untuk mewujudkan nasionalisme yaitu membentuk organisasi-organisasi sebagai wadah 
perlawanan terhadap penjajah. Wujud nasionalisme Indonesia adanya Sumpah Pemuda pada tanggal 28 Oktober 1928, yang berisikan Satu Bahasa, Satu Bangsa, Satu Tanah Air Indonesia. Nasionalisme Indonesia menampakkan wujud formalnya dengan berdiri dan terpenuhinya persyaratan sebagai negara merdeka dan berdaulat.

\section{Konsep Nasionalisme dan Wawasan Kebangsaan}

Konsep nasionalisme dan wawasan kebangsaan pada hakikatnya mengacu pada kesadaran suatu warga negara akan pentingnya ketunggalan bangsa (nation state). Konsep tersebut bersifat idiologis dan disosialisasikan kepada setiap anggota (warga) negara. Nasionalisme dan wawasan kebangsaan mengikat warga negara dalam beberapa hal, yakni (a) memiliki kesadaran sebagai satu bangsa, yang dapat memperkuat rasa kebangsaan, persatuan dan kesatuan, (b) jiwa, semangat, dan nilai-nilai patriotik, yang berkaitan dengan perasaan cinta tanah air, cinta kepada tanah tumpah darah, cinta kepada negara dan bangsa, cinta kepada milik budaya bangsa sendiri, kerelaan untuk membela tanah airnya, (c) jiwa, semangat dan nilai-nilai kreatif dan inovatif, dan (d) jiwa, semangat, dan nilai-nilai yang mampu membentuk kepribadian, watak dan budi luhur bangsa.

Di sisi lain, konsep kebangsaan tidak semata-mata mengacu pada adanya keragaman kultural. Kebangsaan adalah suatu konsep politik, yang perwujudannya hanya bisa diraih lewat upaya-upaya politik pula, dan upaya politik paling penting adalah menciptakan keadilan sosial, tegasnya keberpihakan pada mereka yang lemah. Hanya dengan kebangsaan yang menjamin hak politik warga negara untuk menentukan dirinya sesuai dengan kulturalnya, maka masing-masing kelompok etnis dan budaya yang tergabung di dalamnya akan terjamin menghayati identitasnya.

Nasionalisme Indonesia tidak dapat dipisahkan dari imperialisme dan kolonialisme Belanda, karena sebenarnya nasionalisme merupakan reaksi terhadap bentuk kolonialisme. Hubungan antara keduanya dapat dilihat dalam dua tataran, yaitu tataran universal dan tataran kontekstual. Dalam tataran universal nasionalisme Indonesia pertama-tama adalah sebuah gerakan emasipasi, keinginan mendapatkan atau membangun kembali sebuah dunia yang luas, bebas, yang di dalamnya dan dengannya manusia dapat menghidupkan dan mengembangkan serta merealisasikan dirinya sebagai subjek yang mndiri dan bebas. 
Nasionalisme yang demikian ini dipertentangkan dan imperialisme, yakni upaya melawan segala gerakan yang menghendaki dominasi, superioritas. Dalam tataran universal ini nasionalisme seiring dengan gagasan pembebasan manusia pada umumnya.

Sementara itu dalam tataran kontekstual, nasionalisme Indonesia merupakan kehendak untuk membangun sebuah dunia yang di dalamnya manusia Indonesia, sebagai bagian dari budaya ke-Timur-an, dapat merealisasikan dirinya secara bebas. Di samping itu, manusia Indonesia bisa terlepas dari tekanan dan dominasi penjajahan Belanda, sebagai representasi budaya Barat. Tataran kontekstual ini membatasi gagasan pembebasan hanya pada hubungan antar-bangsa yang dapat membuatnya bertentangan dengan gagasan pembebasan pada tataran yang lebih rendah.

Dalam usaha untuk mewujudkan kehendak di atas orang-orang Indonesia tertarik ke dua arah yang berlawanan, yaitu (1) ada yang bergerak ke masa lalu, dan (2) ada yang bergerak ke masa depan. Mereka yang bergerak ke masa lalu menganggap dunia itu sudah ada sebelumnya dan dapat ditemukan kembali. Sementara yang bergerak ke masa depan mengganggap dunia itu sebagai sebuah bangunan yang akan atau sedang dalam proses pembentukan. Setiap individu yang berada dalam lingkaran suatu generasi mempunyai kewajiban sejarah utntuk menggali dan merumuskan cita-cita kebangsaan sebagai upaya menambah ukiran sejarah perjalanan bangsa.

\section{Hubungan Melunturnya Nasionalisme dengan Kehancuran Bangsa}

Masyarakat, khususnya generasi muda adalah penerus bangsa. Bangsa akan menjadi maju bila para pemudanya memiliki sikap nasionalisme yang tinggi. Namun dengan perkembangan zaman yang semakin maju, malah menyebabkan memudarnya rasa nasionalisme. Nasionalisme sangat penting terhadap kehidupan berbangsa dan bernegara karena merupakan wujud kecintaan dan kehormatan terhadap bangsa sendiri. Atas dasar itu, pemuda dapat melakukan sesuatu yang terbaik bagi bangsanya, menjaga keutuhan persatuan bangsa, dan meningkatkan martabat bangsa dihadapan dunia.

Memudarnya rasa nasionalisme dapat mengancam dan menghancurkan bangsa dari dalam. Hal itu terjadi karena ketahanan nasional akan menjadi lemah dan dapat dengan mudah ditembus oleh pihak luar. Banyak sekali kebudayaan dan paham barat yang masuk ke dalam 
bangsa Indonesia. Banyak budaya dan paham barat yang berpengaruh negatif dapat dengan mudah masuk dan diterima oleh bangsa Indonesia. Dengan terjadinya hal itu, maka akan terjadi akulturasi, bahkan menghilangnya kebudayaan dan kepribadian bangsa yang seharusnya menjadi jati diri bangsa.

Dari aspek perekonomian Negara, dengan memudarnya rasa nasionalisme, mengakibatkan perekonomian bangsa Indonesia jauh tertinggal dari Negara-negara tetangga. Saat ini masyarakat hanya memikirkan apa yang Negara berikan untuk mereka, bukan memikirkan apa yang mereka dapat berikan pada Negara. Dengan keegoisan inilah, masyarakat lebih menuntut hak daripada kewajibannya sebagai warga Negara. Sikap individual yang lebih mementingkan diri sendiri dan hanya memperkaya diri sendiri tanpa memberikan kontribusi nyata pada Negara, mengakibatkan perekonomian Negara semakin lemah.

\section{Peran Pendidikan}

Pendidikan merupakan solusi dari berbagai masalah yang dihadapi bangsa. Pendidikan dapat dikategorikan berhasil, jika hasil yang diinginkan sesuai dengan tujuan yang diharapkan. Berikut peran pendidikan dalam menumbuhkan semangat nasionalisme generasi muda bangsa :

1. Memberikan pelajaran tentang pendidikan pancasila dan kewarganegaraan dan juga bela Negara.

2. Menanamkan sikap cinta tanah air dan menghormati jasa pahlawan dengan mengadakan upacara setiap hari senindan upacara hari besar nasional.

3. Memberikan pendidikan moral, sehingga para pemuda tidak mudah menyerap hal-hal negatif yang dapat mengancam ketahanan nasional.

4. Melatih untuk aktif berorganisasi

5. Menggalakan berbagai kegiatan yang dapat meningkatkan rasa nasionalisme, seperti seminar dan pameran kebudayaan.

6. Mewajibkan pemakaian batik kepada pegawai negeri sipil setiap hari jum'at. $\mathrm{Hal}$ ini dilakukan karena batik merupakan sebuah kebudayaan asli Indonesia, yang diharapkan dengan kebijakan tersebut dapat meningkatkan rasa nasionalisme dan patrotisme bangsa.

7. Lebih mendengarkan dan menghargai aspirasi pemuda untuk membangun Indonesia agar lebih baik lagi.

Sebuah penelitian singkat tentang Semangat Nasionalisme yang 
penulis lakukan di IAIN Pontianak, tergambar sebagai berikut :

\section{Semangat Nasionalisme Mahasiswa}

Jika dari angket yang disebar kepada mahasiswa 13 Jurusan, sebagian besar mahasiswa menjawab semangat nasionalisme masih dianggap baik. Tetapi berbeda dengan wawancara secara langsung kepada mahasiswa. Sebagian besar mahasiswa mengeluhkan motivasi mereka sebagai generasi muda cenderung rendah. Sebagian besar mahasiswa merasa bahwa mereka sekarang ini adalah generasi "galau"; generasi yang sangat mudah terpengaruh dan mengeluh, kurang motivasi dan kreasi. Tetapi dengan adanya kasus penistaan agama yang menjadi trending topic di mass media dan media sosial yang dilakukan oleh calon gubenur Jakarta; Ahok, sebagian kecil mengakui menjadi bersemangat untuk belajar dan membela agama.

Aksi bela Islam 1, 2 dan 3 mampu membuat mereka berkeyakinan bahwa semangat nasionalisme bangsa sesama Muslim masih ada dan sangat kental. Dari Aksi Bela Islam 1, 2 dan 3, mereka pun termotivasi untuk kembali mempelajari sejarah bangsa dan agama.
2. Cara menumbuhkan semangat Nasionalisme

Sesuai data 90\% Mahasiswa menjawab matakuliah Civic Education dan Pancasila telah membantu mahasiswa untuk mencintai tanah air, dan menumbuhkan kembali semangat Nasionalisme. Sedangkan dari hasil wawancara dengan beberapa mahasiswa di sela-sela perkuliahan atau pada waktu tertentu; didapatkan bahwa, menumbuhkan semangat nasionalisme tidak hanya melalui perkuliahan Civic Education dan Pancasila saja, tetapi lebih kepada contoh konkrit dalam keseharian.

Sebagian besar mahasiswa berpendapat, perlu dicari penyebab mengapa semangat nasionalisme masyarakat Indonesia semakin luntur dan terkesan hilang, dan mereka pun setuju bahwa salah satu penyebab melemahnya semangat nasionalisme dalam keberagaman masyarakat Indonesia adalah : doktrin demi doktrin di era globalisasi. Globalisasi telah mampu meyakinkan masyarakat Indonesia bahwa liberalisme dapat membawa kemajuan dan kemakmuran. Sehingga tidak mengherankan perlahan tapi pasti merubah ideologi bangsa dari ideologi Pancasila menjadi ideologi liberalisme. Dari globalisasi ekonomi saja misalnya, 
hilang rasa cinta serta kebanggaan terhadap produk dalam negeri/lokal.

Beberapa

mahasiswa

berpendapat, menumbuhkan semangat nasionalisme adalah tugas utama pemerintah, selain tugas mensejahterahkan dan melindungi seluruh rakyat Indonesia. Pendapat lain semangat nasionalisme sebenarnya tidak akan pernah luntur jika rakyat tidak dibuat bingung oleh pemerintah dan mass media yang sangat tidak pro rakyat khususnya di era kepemimpinan Jokowi. Alternatif solusinya adalah perlu pelestarian budaya di tingkat lokal. Pengenalan budaya sendiri, setidaknya mampu meredam arus globalisasi yang tidak mungkin dapat dibendung.

\section{Kesimpulan}

Dari uraian diatas, dapat disimpulkan beberapa hal sebagai berikut

a. Idealnya, nasionalisme terbentuk dari interaksi antar elemen di dalam suatu bangsa dan tanggapan bangsa itu terhadap lingkungan, sejarah, dan cita-citanya. Substansi nasionalisme Indonesia memiliki dua unsur; Pertama, kesadaran mengenai persatuan dan kesatuan bangsa Indonesia yang terdiri dari suku, etnik, dan agama. Kedua, kesadaran bersama bangsa Indonesia dalam menghapuskan segala bentuk pensubordinasian, penjajahan, dan penindasan dari bumi Indonesia.

b. Pendidikan adalah win win solution untuk menjaga nasionalisme bangsa

c. Generasi muda pada hakikatnya, adalah generasi pemula yang perlu mendapat bimbingan dan arahan oleh generasi sebelumnya. Jika pemimpin Indonesia tidak mampu memberikan tauladan kebaikan, maka berdampak hilangnya semangat nasionalisme. Untuk itulah perlu adanya perbaikan moral pemimpin bangsa. Rakyat harus dicerdaskan dengan tidak lagi memilih sembarang pemimpin dan harus mau memilah media sebagai tambahan ilmu dan informasi.

d. Kampus-kampus Islam khususnya, perlu kembali membudayakan upacara bendera setiap hari senin. Aktifitas ini akan menjadi kebiasaan dan kebutuhan jika dijadikan prioritas untuk kembali menumbuhkan semangat nasionalisme.

e. Pemerintah harus mengupayakan, melahirkan generasi penerus bangsa yang berjiwa nasionalis, religius dan mampu mengembangkan teknologi. Generasi ini adalah generasi terbaik yang mampu membangun Indonesia. Semangat nasionalisme pemuda jika diimbangi. 


\section{Daftar Pustaka}

A.Ubaedillah dkk. 2006. Demokrasi, Hak Asasi Manusia, dan Masyarakat Madani, Jakarta : ICCE UIN Syarif Hidayatullah bekerjasma dengan The Asia Foundation

Ali, Lukman. Dkk. 1994. Kamus Besar Bahasa Indonesia. Jakarta : Balai Pustaka

Burhan, Wirman. 2014. Pendidikan Kewarganegaraan, Pancasila dan Undang-Undang Dasar 1945, Jakarta : PT. RajaGrafindo Persada

Dault, Adhyaksa. 2005. Islam dan Nasionalisme: Reposisi Wacana Universal Dalam Konteks Nasional. Jakarta : Pustaka al-Kautsar

Kaelan. 2010. Pendidikan Pancasila, Yogyakarta : Penerbit Paradigma

Madjid, N. 2004. Indonesia Kita, Jakarta:

PT. Gramedia Pustaka Umum

Maleong, Lexy, J. 1990. Metode

Penelitian Kualitatif. Bandung : PT.

Remaja Rosdakarya

Mulyana, Edi, dan Rakhmat Jalaluddin.

Editor. 1996. Komunikasi

Antarbudaya, Bandung : PT.

Remaja Rosdakarya.

Purwasito, Andrik. 2003. Komunikasi Multikultural, Surakarta

Muhammadiyah University Press.

www. Nasionalisme. com 